Review

\title{
An Overview of Concentrating Photovoltaic Thermal (CPVT) Collectors
}

\author{
${ }^{1}$ Reza Danesh Azarian, ${ }^{2}$ Erdem Cuce and ${ }^{2}$ Pinar Mert Cuce \\ ${ }^{I}$ Department of Renewable Energies Engineering, \\ Faculty of New Sciences and Technologies, University of Tehran, Tehran, Iran \\ ${ }^{2}$ Department Mechanical Engineering, \\ Faculty of Engineering, University of Bayburt, Dede Korkut Campus, 69000 Bayburt, Turkey
}

Article history

Received: 15-06-2017

Revised: 16-06-2017

Accepted: 06-07-2017

Corresponding Author:

Erdem Cuce

Department Mechanical

Engineering, Faculty of

Engineering, University of

Bayburt, Dede Korkut Campus, 69000 Bayburt, Turkey

Emil: erdemcuce@bayburt.edu.tr

\begin{abstract}
Concentrating Photovoltaic Thermal Collectors (CPVT) are in the centre of interest among solar collectors. CPVT collectors' features such as high efficiency and multi-output stimulate researchers and industry partners to focus on this technology. Innovative design is the key point in achieving an efficient collector. In this study, a comprehensive research is conducted on the state-of-theart developments in CPVT collectors covering fundamental basics, system key factors and new advances in design of CPVT collectors. Concentration factor and part, cell type and cooling methods are the most relevant parts of a CPVT collector for optimising and designing an energy-efficient collector. Tracking system has a significant impact on the performance of every solar collector. Parabolic Trough Collector (PTC), Linear Fresnel Reflector (LFR) and dish are used as the concentrating devices in CPVT collectors but nowadays higher concentration factor (600-900) has the leading point. As a consequence of this high concentration thus high temperature in PV cells, cooling system would be a vital part for keeping the collector in its efficient point and Absorption Heat Pumps (AHP) are of significant in this respect to meet the cooling demand. It is concluded from the results that every factor plays a crucial role in overall collector performance, hence they need to be chosen properly for optimum system design.
\end{abstract}

Keywords: Concentrated Photovoltaic Thermal (CPVT) Collectors, Thermal Efficiency, Design Factors

\section{Introduction}

Coupling of Photovoltaic (PV) systems with concentrators such as parabolic trough and dish collectors is an attractive field for solar researches from early 1980s (Evans et al., 1978). CPVT collectors have a remarkable progress among hybrid collector systems. The first CPVT collector is made in Sandia National Laboratories (Lopez and Andreev, 2010). The advances in PV (Cuce et al., 2013; 2014; 2015; Cuce and Cuce, 2012; Cuce et al., 2017; Cuce and Riffat, 2017; Cuce, 2016; Cuce et al., 2016a; 2016b; 2015; Cuce, 2014; Cuce and Cuce, 2014; Cuce, 2009; Cuce and Bali, 2010; 2009a; 2009b; 2009c; Young et al., 2015; Alotaibi et al., 2015; Azarian et al., 2016), Concentrated Photovoltaic (CPV) and Photovoltaic Thermal (PVT) systems (Riffat and Cuce, 2011; Cuce et al., 2011; Cuce and Cuce, 2014; Cuce, 2015; Cuce and Cuce, 2013a; 2013b) stimulate the technological developments of CPVT collectors as it is well-documented in literature. Several CPVT systems are designed and manufactured for numerical and experimental investigations. CPVT collectors have high optical and thermal efficiencies, for example overall efficiency of these systems is more than $65.1 \%$ (Kandilli, 2013) and the outlet temperature of working fluid is approximately $200^{\circ} \mathrm{C}$ (Zhao et al., 2011). The costs and payback period of said systems are very low according to their performance. For instance, cost of electricity in a CPVT collector is reported to be $2.37 \$ / \mathrm{W}$ (Xu et al., 2015) and total electrical and thermal costs are $8.7 \$ / \mathrm{W}$ (Quaia et al., 2012).

There are several studies in literature on the field of PVT (Avezov et al., 2011; Singh and Othman, 2009; Makki et al., 2015), CPV (Chemisana, 2011; Royne et al., 2005; Zahedi, 2011; Xie et al., 2011) and CPVT (Sharaf and Orhan, 2015) systems. However, there is not a review on the fundamentals and state-of-the-art of CPVT systems. In this study, a brief and complete review on the CPVT technology focused on the fundamentals, concept, design and test of CPVT solar collectors is presented. In the research, a CPVT collector 
is split into its elements to clarify the subsystems with their characteristic features. Both CPV and concentrated solar thermal systems are the main parts of CPVT collectors, so analysing these elements would help understanding the complete systems.

The most important factor in the CPV collectors is their concentration ratio. The highly CPVT systems could lead to a small cell surface, so this cost saving issue could be used for efficient multi-junction solar cells. The multi-junction solar cells have high performance figures and efficiencies which could reach more than 40\% (Kurtz and Geisz, 2010; Yamaguchi et al., 2005; Dimroth et al., 2014). For an efficient CPVT system, PV modules are expected to have an efficiency above 30\% (Araki et al., 2005; Kinsey et al., 2011; Van Riesen et al., 2011).

Focusing on the type of the concentrating collector in a CPVT system, it is common to use dish parabolic, parabolic trough and linear Fresnel reflectors. It needs to be mentioned that linear and point concentration is the main difference in the concentration process of the collectors. There is a great interest and progress in CPVT technologies within the last decade. Fresnel lens reflectors are one of the best collectors to be used in CPVT systems. These collectors have advantages such as small size, lightweight structure and low cost. Araki et al. (2010) investigate a CPVT system using Fresnel lenses. Their collector efficiency and the nominal power generation are reported to be $25.8 \%$ and $30 \mathrm{~kW}$, respectively. A review study is done by Xie et al. (2011) on the concentrated solar application using linear Fresnel reflectors.

\section{Concept}

CPV systems concentrate the solar beams on the PV cells. High performance PV cells are expensive and CPV collectors overcome this drawback. In CPV collectors, concentrated solar beams are reflected on the PV cells which are more cost-effective than stand-alone PV cells. Therefore, the efficiency of this system would be higher than a common PV cell and this enhancement occurs with lower costs. On the other hand, the number of PV cells would be decreased by using CPV collectors. Also, PVT collector needs to be taken into account to generate both thermal and electrical energy simultaneously. The back temperature of PV cells would be a waste heat recovery for increasing the performance of these cells by cooling and absorbing the thermal energy for other applications such as space heating or water heating. CPVT system is a hybrid application of PVT and CPV collectors for achieving more performance. There are two disadvantages of PVT systems; First, generating desired amount of electrical energy from PV cells needs high investments. Second, the thermal energy of these systems are used for only low-temperature applications.
In a CPVT system, both of these demerits are covered by maintaining the PV cells in a moderated temperature and utilizing the spectrum concentration. The main elements and methodologies of performance assessment of a CPVT system are given in Fig. 1.

\section{Concept}

Design and manufacturing of CPVT systems are of vital importance for overall performance of these collectors. In this respect, at the beginning, the purpose of using a CPVT collector needs to be clarified that either it would be utilised for domestic application or industrial processes. Therefore, key factors are required to be discussed in this section. Vital merits of CPVT collectors are the same as PVT and CPV collectors such as $\mathrm{CO}_{2}$ free system, saving fossil fuels and water resources. Key factors in designing CPVT systems are associated with the optimum devise of CPV and PVT collectors. CPVT systems have multi-output generation, high-value thermal energy, high total efficiency, less number of PV cells and low cell temperatures. On the other hand, some disadvantages of these collectors are their complexity, PV overheating and high PV series resistance.

\section{Thermodynamic Review}

In a typical CPV system, more than the half of the radiative energy is transformed to waste heat (Chow, 2010). But in a CPVT system, most of the waste heat enters to the heat extraction section. CPVT collector has higher useful energy in comparison with other solar collectors. Second thermodynamic analysis of CPVT collectors shows that the electrical and thermal useful outputs are not equal, even if they could be equal according to the first law. Coventry and Lovegrove (2003) evaluate the different methods for finding an electrical to thermal ratio representing the useful energy conversion in a system. This ratio is defined as follows:

$E_{\text {ele.eq }}=\frac{E_{\text {th }}}{\delta}+E_{\text {ele }}$

Studying the energy analysis of a CPVT collector which is in relation with second law of thermodynamics, is more important than the energy analysis based on first law of thermodynamics. Energy analysis is basic and considered as the best optimization method for CPVT collector. Huang et al. (2001) represent the Primary Energy Saving (PES) efficiency for a CPVT systems as follows:

$\eta_{P E S}=\frac{E_{E L E}}{\eta_{P E S-e l e}}+\frac{E_{t h}}{\eta_{P E S-t h}}$ 


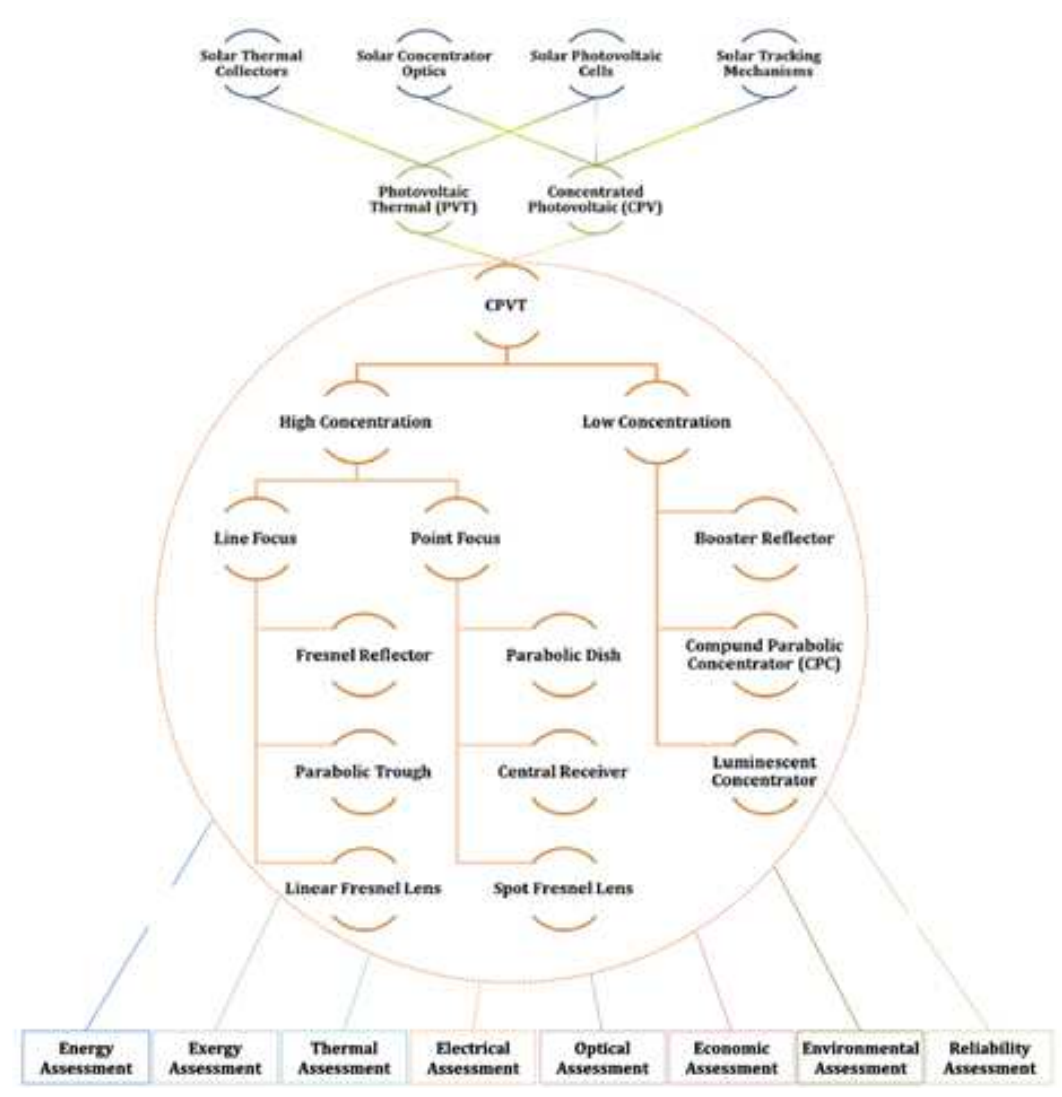

Fig. 1. CPVT systems with main elements and performance assessment strategies (Sharaf and Orhan, 2015)

In the said equations, $E_{\text {ele }}$, eq is the equivalent electrical energy cost, $E_{\text {ele }}$ is the electrical energy, $E_{t h}$ is the thermal energy, $\delta$ is the electrical to thermal ratio, $\eta_{P E S}-e l s$ and $\eta_{P E S}-t h$ are the efficiency of primary energy saving to electrical and thermal energy, respectively. The thermal efficiency is multiplied by a Carnot factor in Otanicar et al. (2010) CPVT model. 0.5 Estimation is considered for Carnot factor which is the ideal Carnot efficiency. Xu et al. (2011) conduct an experimental research on the low concentrating PVT system. Their CPVT system is used for water heating and the schematic diagram of their design is shown in Fig. 2. In the said system, the thermal energy content of 80 litre water is enhanced from 30.9 to $70^{\circ} \mathrm{C}$ and the volumetric flow rate of circulating water is reported to be $0.45 \mathrm{~m} \mathrm{~m}^{3} / \mathrm{h}$. The variations of solar radiation and ambient temperature for the experimental period is shown in Fig. 3.

\section{PV Cells}

Four generations of PV cells are constructed and first two generations are commercially available. Choosing the best PV cell is the key point which has a significant impact on the performance of a CPVT system. Da Silva and Fernandes (2010) investigate the thermal and electrical performances of their PVT system. They use monocrystalline, polycrystalline and amorphous silicon PV cells. Their results are shown in Fig. 4. The monocrystalline cells perform the best efficiency as expected. They evaluate different types of single-junction PV material by considering various band gap energies impacts on the thermal, PV cell efficiency and overall efficiency of a CPVT collector.

High efficiency PV cells are not always the best choice (Li et al., 2011). Several important factors such as cell cost, heat extraction method and concentration ratio have significant impact on the option of PV cell. Multijunction or non-silicon PV cells are appropriate for highly CPVT systems, on the other hand, for low concentration ratios, common crystalline PVs are better because of their lower costs. Due to Shockley-Queisser balance limit, the maximum efficiency of a p-n junction PV cell with $1.1 \mathrm{eV}$ band gap is $33 \%$ (Shockley and Queisser, 1961) and could reach $40.7 \%$ by considering the maximum concentration ratio (Araújo and Martí, 1994). Da Rosa (2013) represent a detailed correlation for the efficiency of a PV cell as follows:

$$
\begin{aligned}
& \eta_{\text {c.ideal }}=1780 \frac{V_{g}}{T} \int_{q V g / k T}^{\infty}\left(\frac{x^{2}}{e^{x}-1}\right) d x \\
& x=\frac{h c}{k T \lambda}
\end{aligned}
$$




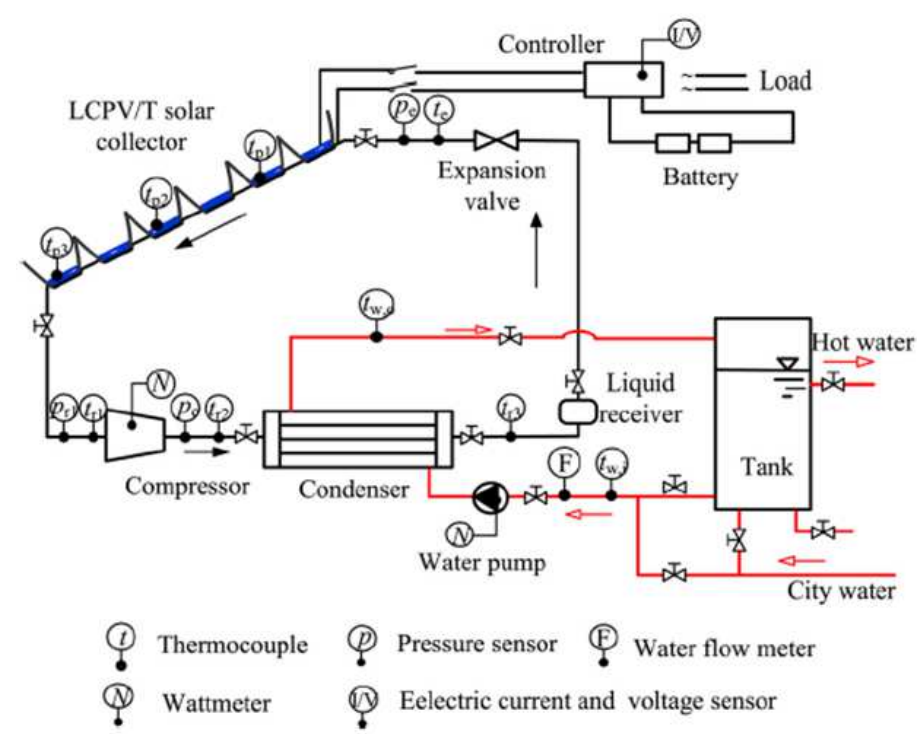

Fig. 2. Schematic diagram of the novel CPVT system (Xu et al., 2011)

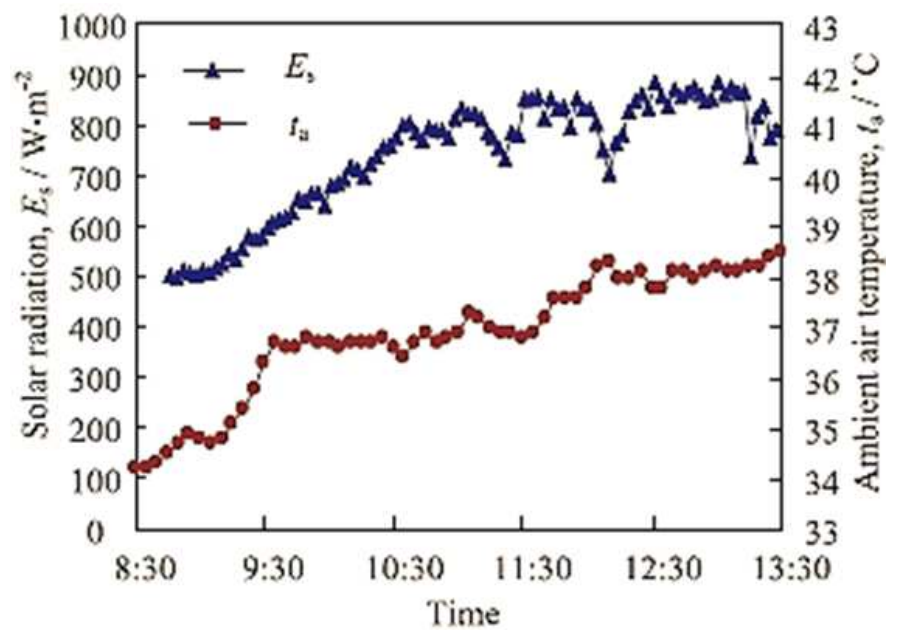

Fig. 3.Variations of solar radiation and ambient temperature for Xu et al. (2011)

In Equation 4, $c$ is the speed of light Total conversion efficiency of a PV cell is defined by:

$$
\eta_{P V}=\frac{P_{e l e}}{G A}=\frac{V_{o c} I_{s c} F F}{G A}
$$

where, $P_{\text {ele }}$ is the maximum power output of PV cell, $G$ is the solar intensity, $A$ is the surface area of PV cell, $V_{o c}$ is the open circuit voltage, $I_{s c}$ is the short-circuit current and $F F$ is the fill factor. The Structure of a InGaP/InGaAs/Ge triple-junction PV stack (Nishioka et al., 2006) is shown in Fig. 5.

\section{Material between PV Cells and Thermal Collector}

The material which is used for this section is expected to have a high thermal conductivity, high electrical insulation, high resistivity to thermal shocks and low cost. Rosell et al. (2005) investigate the effect of adhesive on the thermal efficiency of CPVT systems. Their results show that $13.5 \%$ enhancement in the thermal efficiency of the collector is achieved by increasing $100 \%$ thermal conductivity of the adhesive. Dupeyrat et al. (2011) present a technique in which the front glazing, adhesive material, PV cells and absorber are laminated in one step. About $600 \%$ enhancement is obtained in thermal conductivity.

There are two ways of cooling for the PV modules which are called as active and passive cooling. One of the efficient collectors for the CPVT systems is point-focus Fresnel systems. In these units, the modules are cooled passively. It is reported in previous works (Xie et al., 2011) that the passive cooling needs to be done for single cell geometries and high concentration ratio like 1000 suns. 


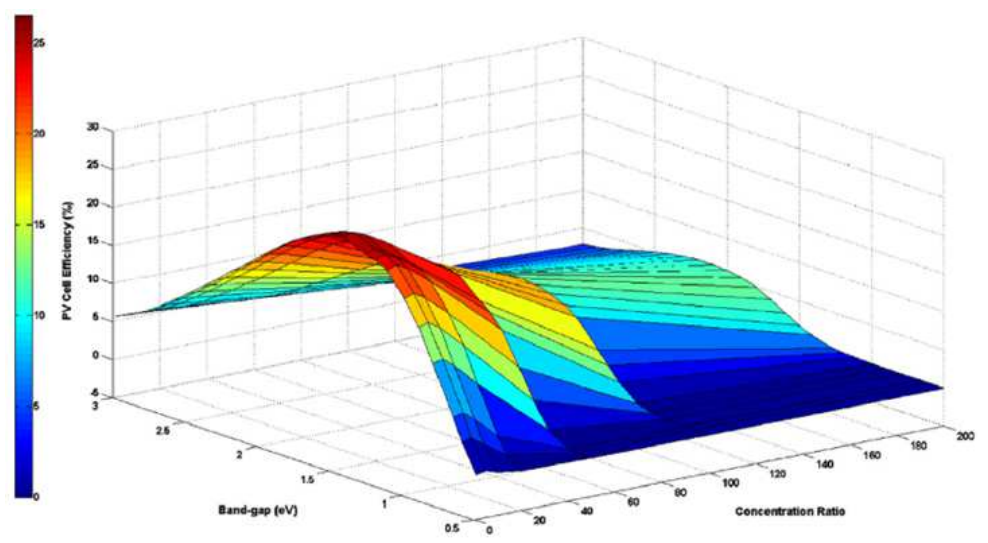

(a)

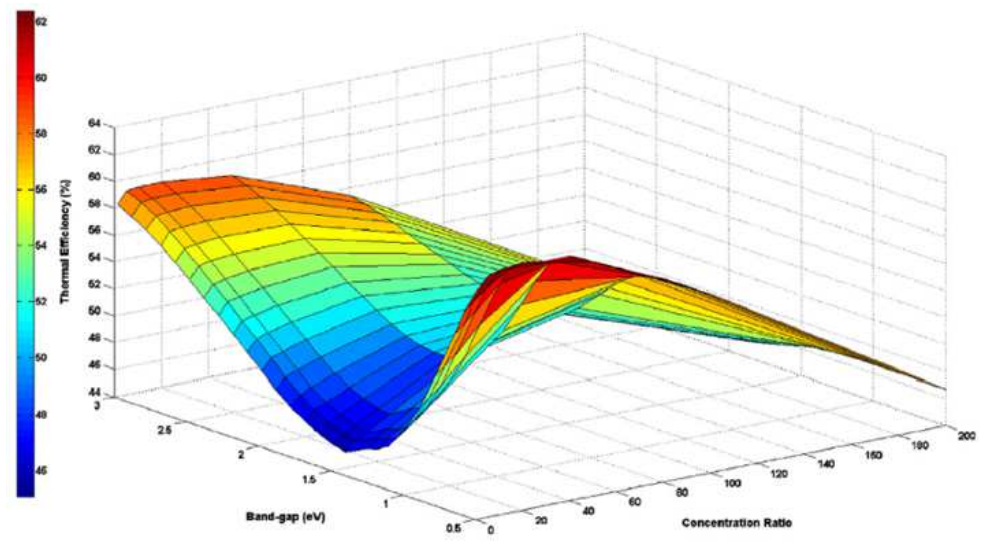

(b)

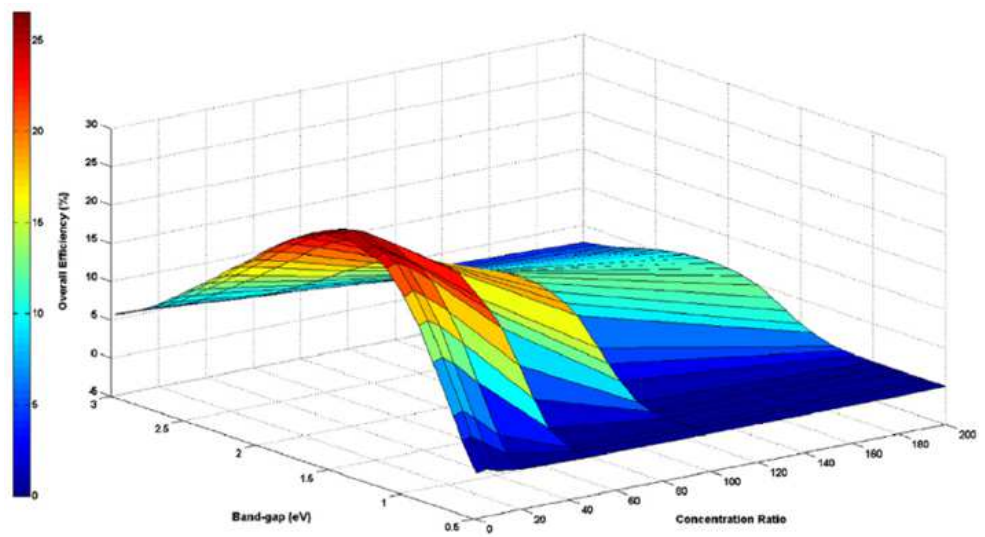

(c)

Fig. 4. Variation of CPVT's (a) electrical, (b) thermal and (c) total efficiency with bandgap energy and concentration ratio (Da Silva and Fernandes, 2010)

The reason for the assumption is the large available area for heat sink. On the other hand, a large portion of solar radiation is dissipated as waste heat from the modules and it is a way of passive cooling. In the active type, heat transfer from the central absorber to the working fluid could be enabled with a thermal circulation and it can be absorbed as useful energy. This enhancement can increase the overall thermal efficiency. The heat recovery can be used for a domestic and industrial system through applications of solar cooling, air conditioning (Balaras et al., 2007; Mittelman et al., 2007) and solar desalination (Koschikowski et al., 2009; Mittelman et al., 2009). 


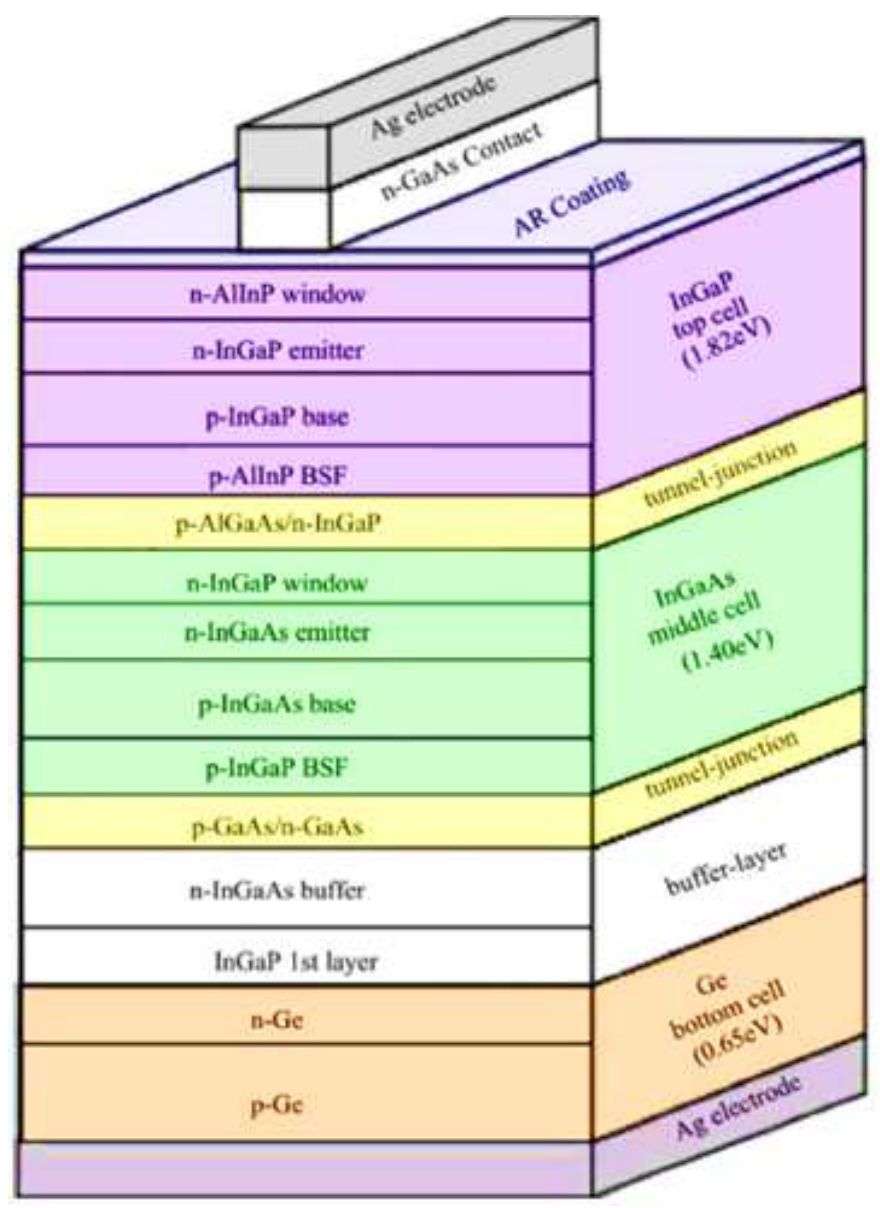

Fig. 5. Structural details of a InGaP/InGaAs/Ge triple-junction PV stack (Nishioka et al., 2006)

\section{Material between PV Cells and Thermal Collector}

Another critical part of a CPVT system is its solar thermal collector. Flat plate, parabolic trough, dish and evacuated tube collectors are the most common types which are utilized in CPVT collectors. Sharan et al. (1987) consider a linear CPVT unit. They examine tubular, horizontal flat plate and vertical flat plate collectors. Tubular demonstrate the best results by considering both thermal and electrical efficiencies. There are two kinds of solar thermal collectors which are used in the CPVT systems; non-concentrated solar collectors such as flat plate collectors and evacuated tube collectors and concentrated collectors such as dish collectors and parabolic trough collectors. A schematic of a flat plate collector is shown in Fig. 6 (Sozen et al., 2008).

In a flat plate collector, the glass cover is used for minimizing the convection heat losses and transmittance of long wave radiations from the absorber tube. For the absorber plate, selective coating is utilised. For cold environmental conditions, it is better to use evacuated tube collectors instead of flat plate collectors. In an evacuated tube collector, a heat pipe is surrounded by a vacuum tube. This vacuum reduces the convection and the conduction heat losses. The pipe is coupled with an absorber plate and a working fluid like methanol evaporates in the evaporator segment. In the CPVT systems, expensive PV cells are replaced with cheaper ones as mentioned before. The energy conversion efficiency increases by the increase of the solar intensity. The reduction ratio for the cell number could be reached even to 1000 and this reduction would decrease the cost per $\mathrm{kW}$ (Algora et al., 2006). CPV collectors are classified for four levels: Low concentration ratio (1-10 suns), medium (10-80 suns), high (80-500 suns) and ultra-high ( $>500$ suns). Linear Fresnel Reflectors (LFR) are the most common types utilised in CPVT systems. However, parabolic dish collector (Verlinden et al., 2008), central receiver systems (Lasich et al., 2009) and parabolic trough collectors (Yadav et al., 2013) are also used in CPVT systems. Different types of concentrating solar collectors are shown in Fig. 7 (Verlinden et al., 2008; Lasich et al., 2009; Yadav et al., 2013; Luque and Andreev, 2007; Schuetz et al., 2012). Different types of solar thermal collectors with the concentration ratio, operating temperature and efficiency ranges are illustrated in Table 1. 

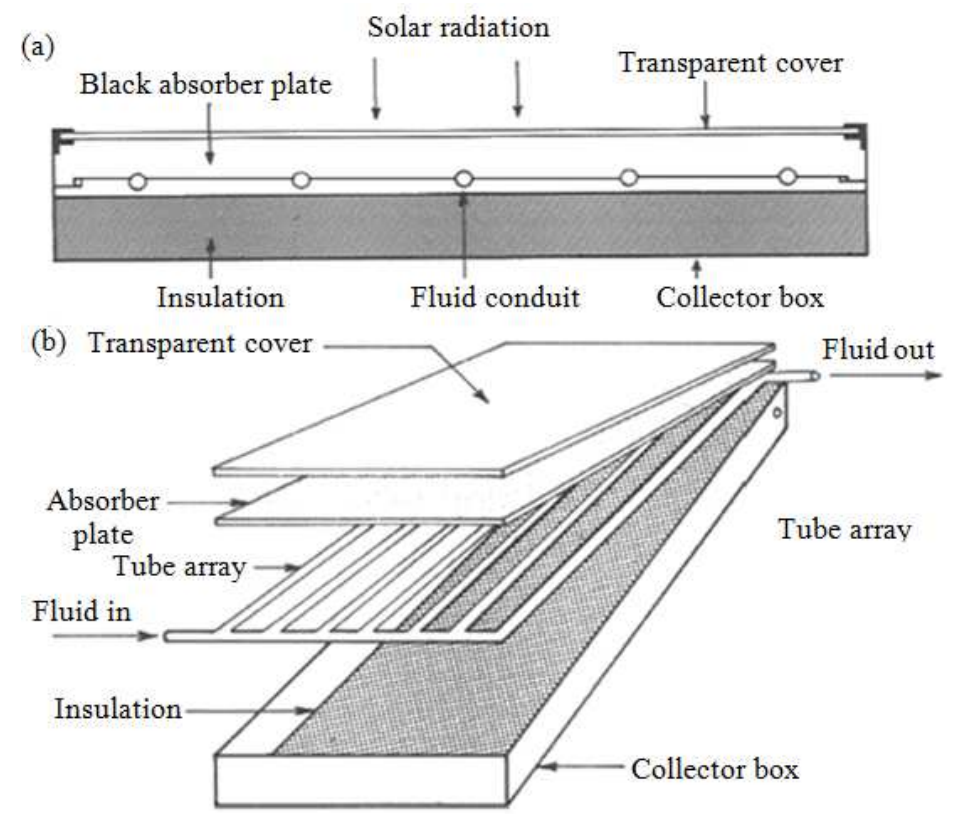

Fig. 6. (a) Cross-sectional and (b) isometric schematic views of a flat-plate solar collector (Sozen et al., 2008)

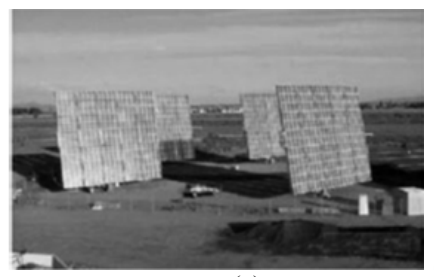

(a)

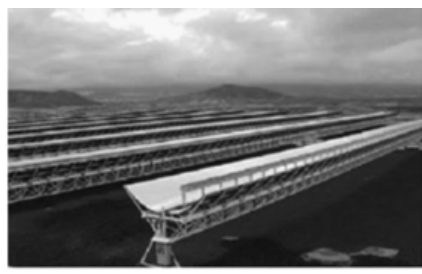

(b)

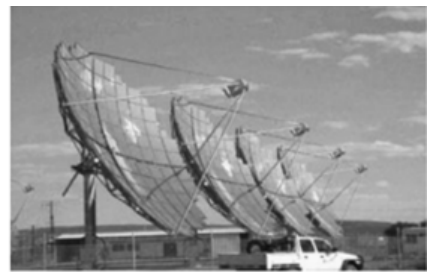

(c)

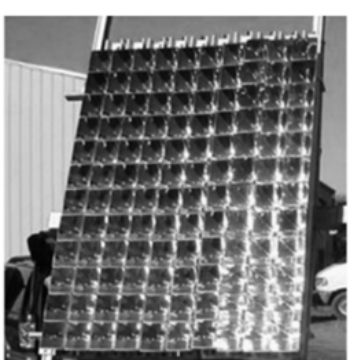

(d)

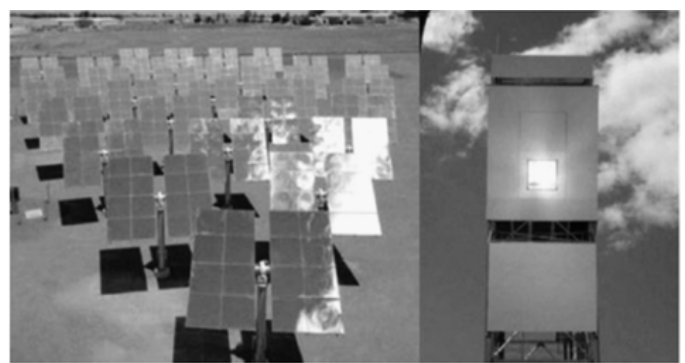

(e)

Fig. 7. (a) Fresnel lenses (Luque and Andreev, 2007), (b) parabolic trough (Luque and Andreev, 2007), (c) parabolic dish (Lasich et al., 2009), (d) compound parabolic concentrators (Schuetz et al., 2012) and (e) heliostat field central receiver (Lasich et al., 2009)

Table 1. Solar thermal collectors with efficiency, operating temperature and concentration ratio ranges

\begin{tabular}{llll}
\hline Technology & Concentration ratio & Operating temp $\left({ }^{\circ} \mathrm{C}\right)$ & Efficiency $(\%)$ \\
\hline Flat Plate Collector (FPC) & 1 & $35-65$ & $45-60$ \\
Evacuated Tube Collector (ETC) & 1 & $50-100$ & $30-50$ \\
FPC coupled with booster reflectors & $1-3$ & $40-80$ & $30-50$ \\
ETC coupled with booster reflectors & $1-3$ & $70-120$ & $40-50$ \\
Compound Parabolic Concentrator (CPC) & $1-5$ & $50-120$ & $30-40$ \\
Parabolic Trough Collector (PTC) & $40-80$ & $350-450$ & $14-16$ \\
Linear Fresnel Reflector (LFR) & $20-50$ & $200-350$ & $8-10$ \\
Parabolic Dish Collector (PDC) & $800-5000$ & $500-1200$ & $20-30$ \\
Heliostat Field Central Receiver (HFCR) & $500-1200$ & $500-1000$ & $12-18$ \\
\hline
\end{tabular}




\section{Heat Transfer Fluid (HTF)}

For HTF, water is the common working fluid owing to its high specific heat capacity. Some low concentration ratio CPVT systems use air for their HTF. It is reported in literature that the CPVT collectors which use water as HTFhave higher thermal and electrical efficiencies (Tripanagnostopoulos et al., 2002). Using solid nanoparticles in the HTF is the new horizon for achieving effective collectors. The volume fraction, mass flow rate, size of the nanoparticles and ambient conditions are the important factors for HTF to achieve high performance.

\section{PV Cell Temperature}

The high back temperature of PV cells causes a great decrease in the performance of the system. The PV cell temperature is usually expressed as a function of reference conditions as follows (Skoplaki and Palyvos, 2009):

$$
\eta=\eta_{r e f}\left[1-\delta_{r e f}\left(T_{p v}-T_{a}\right)\right]
$$

In the said equation, $\eta_{r e f}$ is the reference efficiency specified at standard test conditions, $\delta_{r e f}$ is the temperature coefficient, $T_{p v}$ is the $\mathrm{PV}$ cell temperature and $T_{a}$ is the ambient temperature. Inlet temperature of the HTF has a significant effect on the PV cell temperature (Shan et al., 2013).

\section{Heat Extraction System}

It is important to emphasise this issue that the cooling process at the back of the cells is done simultaneously with the harvesting of the thermal energy. The important difference between CPV systems and CPVT collector is in the management of the PV cells' back thermal. In CPV systems this heat is dissipated but in CPVT systems it is utilized. For decreasing the PV cell temperature, a reliable heat extraction mechanism needs to be considered. According to the heat removal systems, PV cells in the CPVT system have higher lifetime in comparison with common PV cells. Two different mechanisms are used for this purpose. In the first method, the unutilised radiation (useless radiation for the cells) is collected before the access of this radiation to the PV cells. This mechanism is done by spectral decomposition and direct absorption heat transfer fluids. Spectral decompositions such as beam spilling filters (Mojiri et al., 2013), heat mirrors (Kandilli, 2013) and holographic concentrators (Kumar et al., 2008) or nanofluids (Khullar, 2013) could be used for direct absorption HTF. In the second mechanism, the increased thermal energy inside the PV cell is gathered after the access of unutilised radiation. This method is the most common mechanism for collecting the thermal energy. For this technique, pressure drop minimising, thermal resistance minimising and obtaining a uniform temperature profile are the common processes.

\section{Conclusion}

CPVT systems are considered as the most efficient collector type among the solar collectors. This study provides key findings on the fundamentals and design aspects of CPVT collectors. The design of CPVT collectors has different parameters which have significant impacts on the reliability, durability and the performance of these collectors:

- The first key parameter is the solar thermal collector. Concentrating solar collector such as parabolic dish collectors and parabolic trough collectors have better thermal and optical efficiency compared to nonconcentrated collectors

- CPVT systems unlike the CPV collector provide heat transfer enhancement due to the waste heat recovery from the PV cells. This recovered thermal energy can be utilised for mid-temperature applications

- Heat Transfer Fluid (HTF) circulates the absorbed thermal energy from the absorber. The heat absorption can be improved by using nanoparticles in the working fluid such as water, thermal oil and ethylene glycol

- Considering CPVT systems can increase the efficiency of the system through additional solar radiation falling on PV cells and thus can decrease the cost due to reduction of the cells numbers

\section{Author's Contributions}

Reza Danesh Azarian: Preparation of the main draft following the collecting data and evaluating the findings.

Erdem Cuce and Pinar Mert Cuce: Revising the draft and mentoring the research.

\section{Ethics}

This article is original and contains unpublished material. The corresponding author confirms that all of the other authors have read and approved the manuscript and no ethical issues involved.

\section{References}

Algora, C., I. Rey-StolleI, B. Galiana, J. Gonzalez and M. Baudrit et al., 2006. Strategic options for a led-like approach in III-V concentrator photovoltaics. Proceedings of the IEEE 4th World Conference on Photovoltaic Energy Conversion, Conference Record, May 7-12, IEEE Xplore Press, Waikoloa, HI, pp: 741-744. DOI: 10.1109/WCPEC.2006.279562

Alotaibi, A., S.B. Riffat and E. Cuce, 2015. Photovoltaic vacuum glazing for low carbon buildings. Proceedings of the 14th International Conference on Sustainable Energy Technologies, Aug. 25-27, Nottingham, United Kingdom. 
Araki, K., H. Uozumi, T. Egami, M. Hiramatsu and Y. Miyazaki et al., 2005. Development of concentrator modules with dome-shaped fresnel lenses and triple-junction concentrator cells. Progress Photovoltaics Res. Applic., 13: 513-527.

Araki, K., T. Yano and Y. Kuroda, 2010. $30 \mathrm{~kW}$ concentrator photovoltaic system using dome-shaped Fresnel lenses. Opt. Express, 18: A53-A63.

Araújo, G.L. and A. Martí, 1994. Absolute limiting efficiencies for photovoltaic energy conversion. Solar Energy Mater. Solar Cells, 33: 213-240.

Avezov, R.R., J.S. Akhatov and N.R. Avezova, 2011. A review on Photovoltaic-Thermal (PV-T) air and water collectors. Applied Solar Energy, 47: 169-183.

Azarian, R.D., E. Cuce and P.M. Cuce, 2016. Concentrated Photovoltaic Thermal (CPVT) solar collector systems: State-of-the-art, fundamental and design key-factors. Proceedings of the 15th International Conference on Sustainable Energy Technologies, Jul. 19-22, Singapore.

Balaras, C.A., G. Grossman, H.M. Henning, C.A.I. Ferreira and E. Podesser et al., 2007. Solar air conditioning in Europe-an overview. Renewable Sustainable Energy Rev., 11: 299-314. DOI: 10.1016/j.rser.2005.02.003

Chemisana, D., 2011. Building integrated concentrating photovoltaics: A review. Renewable Sustainable Energy Rev., 15: 603-611.

Chow, T.T., 2010. A review on photovoltaic/thermal hybrid solar technology. Applied Energy, 87: 365-379.

Coventry, J.S. and K. Lovegrove, 2003. Development of an approach to compare the "value" of electrical and thermal output from a domestic PV/thermal system. Solar Energy, 5: 63-72.

Cuce E., 2016. Toward multi-functional PV glazing technologies in low/zero carbon buildings: Heat insulation solar glass-latest developments and future prospects. Renewable Sustainable Energy Rev., 60: 1286-1301.

Cuce, E. and P.M. Cuce, 2013a. Tilt angle optimization of Building-Integrated Photo Voltaics (BIPVs) for cooler operating temperatures. Proceedings of the MEGS Annual Conference, Public Engagement with Energy, Sep. 12-13, Loughborough, United Kingdom.

Cuce, E. and P.M. Cuce, 2014. Improving thermodynamic performance parameters of silicon photovoltaic cells via air cooling. Int. J. Ambient Energy, 35: 193-199.

Cuce, E. and P.M. Cuce, 2014. Tilt angle optimization and passive cooling of Building-Integrated Photo Voltaics (BIPVs) for better electrical performance. Arab. J. Sci. Eng., 39: 8199-8207.

Cuce, E. and S.B. Riffat, 2017. A smart building material for low/zero carbon applications: Heat insulation solar glass-characteristic results from laboratory and in-situ tests. Int. J. Low-Carbon Technol., 12: 126-135.
Cuce, E. and T. Bali, 2009a. Comparison of energy, power conversion and exergy efficiencies of monocrystalline silicon photovoltaic module at different illumination intensities and cell temperatures. Proceedings of the 17. Ulusal Isı Bilimi ve Teknigi Kongresi, Jun. 24-27, Sivas, Turkey.

Cuce, E. and T. Bali, 2009b. A comparison of energy and power conversion efficiencies of $\mathrm{m}-\mathrm{Si}$ and $\mathrm{p}-\mathrm{Si}$ PV cells in Trabzon. Proceedings of the 5th International Advanced Technologies Symposium, May 13-15, Karabuk, Turkey.

Cuce, E. and T. Bali, 2009c. Variation of cell parameters of a $\mathrm{p}-\mathrm{Si} \mathrm{PV}$ cell with different solar irradiances and cell temperatures in humid climates. Proceedings of the 4th International Exergy, Energy and Environment Symposium, Apri. 19-23, Sharjah, United Arab Emirates.

Cuce, E. and T. Bali, 2010. Improving performance parameters of silicon solar cells using air cooling. Proceedings of the 5th International Ege Energy Symposium and Exhibition, Jun. 27-30, Denizli.

Cuce, E., 2009. Thermodynamic analysis of the effectiveness of different types of PV modules for wet conditions. PhD Thesis, Karadeniz Technical University.

Cuce, E., 2014. Development of innovative window and fabric technologies for low-carbon buildings. Ph.D. Thesis, University of Nottingham.

Cuce, E., 2015. Toward thermal super insulation technologies in buildings: Latest developments in glazing and building fabric. LAP Lambert Academic Publishing, Saarbrücken, Germany.

Cuce, E., C.H. Young and S.B. Riffat, 2014. Performance investigation of heat insulation solar glass for low-carbon buildings. Energy Conversion Manage., 88: 834-841.

Cuce, E., C.H. Young and S.B. Riffat, 2015. Thermal insulation, power generation, lighting and energy saving performance of heat insulation solar glass as a curtain wall application in Taiwan: A comparative experimental study. Energy Convers. Manage., 96: 31-38.

Cuce, E., C.H. Young and S.B. Riffat, 2015. Thermal performance investigation of heat insulation solar glass: A comparative experimental study. Energy Build., 86: 595-600.

Cuce, E., D. Harjunowibowo and P.M. Cuce, 2016b. Renewable and sustainable energy saving strategies for greenhouse systems: A comprehensive review. Renewable Sustainable Energy Rev., 64: 34-59.

Cuce, E., P.M. Cuce and C.H. Young, 2016a. Energy saving potential of heat insulation solar glass: Key results from laboratory and in-situ testing. Energy, 97: 369-380. 
Cuce, E., P.M. Cuce and T. Bali, 2013. An experimental analysis of illumination intensity and temperature dependency of photovoltaic cell parameters. Applied Energy, 111: 374-382.

Cuce, E., P.M. Cuce, I.H. Karakas and T. Bali, 2017. An accurate model for Photovoltaic (PV) modules to determine electrical characteristics and thermodynamic performance parameters. Energy Convers. Manage., 146: 205-216.

Cuce, E., T. Bali and S.A. Sekucoglu, 2011. Effects of passive cooling on performance of silicon photovoltaic cells. Int. J. Low-Carbon Technol., 6: 299-308.

Cuce, P.M. and E. Cuce, 2012. A novel model of photovoltaic modules for parameter estimation and thermodynamic assessment. Int. J. Low-Carbon Technol., 7: 159-165.

Cuce, P.M. and E. Cuce, 2013b. Passive cooling of Building-Integrated Photo Voltaics (BIPVs) for better electrical performance. Proceedings of the MEGS 4th Annual Conference, Public Engagement with Energy, Sep. 12-13, Loughborough, United Kingdom.

Da Rosa, A.V., 2013. Fundamentals of Renewable Energy Processes. 1st Edn., Elsevier Science, Burlington.

Da Silva, R.M. and J.L.M. Fernandes, 2010. Hybrid Photovoltaic/Thermal (PV/T) solar systems simulation with Simulink/Matlab. Solar Energy, 84: 1985-1996.

Dimroth, F., M. Grave, P. Beutel, U. Fiedeler and C. Karcher et al., 2014. Wafer bonded four-junction GaInP/GaAs//GaInAsP/GaInAs concentrator solar cells with $44.7 \%$ efficiency. Progress Photovolta. Res. Applic., 22: 277-282.

Dupeyrat, P., C. Ménézo, M. Rommel and H.M. Henning, 2011. Efficient single glazed flat plate photovoltaicthermal hybrid collector for domestic hot water system. Solar Energy, 85: 1457-1468.

Evans, D.L., W.A. Facinelli and R.T. Otterbein, 1978. Combined photovoltaic/thermal system studies. Arizona State Univ.

Huang, B.J., T.H. Lin, W.C. Hung and F.S. Sun, 2001. Performance evaluation of solar photovoltaic/thermal systems. Solar Energy, 70: 443-448.

Kandilli, C., 2013. Performance analysis of a novel concentrating photovoltaic combined system. Energy Convers. Manage., 67: 186-196.

Khullar, V., 2013. Solar energy harvesting using nanofluids-based concentrating solar collector. J. Nanotechnol. Eng. Med.

Kinsey, G.S., A. Nayak, M. Liu and V. Garboushian, 2011. Increasing power and energy in amonix CPV solar power plants. IEEE J. Photovolta., 1: 213-218.

Koschikowski, J., M. Wieghaus and M. Rommel, 2009. Membrane distillation for solar desalination in Seawater Desalination. Green Energy Technol.
Kumar, A., N. Deo and H.L. Yadav, 2008. Analysis of design parameters for wavelength selective holographic solar concentrators. Proceedings of the 33rd IEEE Photovoltaic Specialists Conference, May 11-16, IEEE Xplore Press, San Diego, pp: 1-4. DOI: $10.1109 /$ PVSC.2008.4922898

Kurtz, S. and J. Geisz, 2010. Multijunction solar cells for conversion of concentrated sunlight to electricity. Optics Express, 18: A73-A78.

Lasich, J.B., P.J. Verlinden, A. Lewandowski, D. Edwards and H. Kendall et al., 2009. World's first demonstration of a $140 \mathrm{kWp}$ Heliostat Concentrator PV (HCPV) system. Proceedings of the IEEE 34th Photovoltaic Specialists Conference, Jun. 7-12, IEEE Xplore Press, Philadelphia, PA, pp: 22752280. DOI: $10.1109 /$ PVSC.2009.5411354

Li, M., X. Ji, G.L. Li, Z.M. Yang and S.X. Wei et al., 2011. Performance investigation and optimization of the trough concentrating photovoltaic/thermal system. Solar Energy, 85:1028-1034.

Lopez, A.L. and V.M. Andreev, 2010. Concentrator Photovoltaics. 1st Edn., Springer, Berlin, Germany.

Luque, A.L. and V.M. Andreev, 2007. Concentrator Photovoltaics. 1st Edn., Springer, Berlin.

Makki, A., S. Omer and H. Sabir, 2015. Advancements in hybrid photovoltaic systems for enhancedsolar cells performance. Renewable Sustainable Energy Rev., 41: 658-684.

Mittelman, G., A. Kribus and A. Dayan, 2007. Solar cooling with Concentrating Photovoltaic/Thermal (CPVT) systems. Energy Convers. Manage., 48: 2481-2490.

Mittelman, G., A. Kribus, O. Mouchtar and A. Dayan, 2009. Water desalination with Concentrating Photovoltaic/Thermal (CPVT) systems. Solar Energy, 83: 1322-1334.

Mojiri, A., R. Taylor, E. Thomsen and G. Rosengarten, 2013. Spectral beam splitting for efficient conversion of solar energy-a review. Renewable Sustainable Energy Rev., 28: 654-663.

Nishioka, K., T. Takamoto, T. Agui, M. Kaneiwa and Y. Uraoka et al., 2006. Annual output estimation of concentrator photovoltaic systems using highefficiency $\mathrm{InGaP} / \mathrm{InGaAs} / \mathrm{Ge}$ triple-junction solar cells based on experimental solar cell's characteristics and field-test meteorological data. Solar Energy Mater. Solar Cells, 90: 57-67.

Otanicar, T., I. Chowdhury, P.E. Phelan and R. Prasher, 2010. Parametric analysis of a coupled photovoltaic/thermal concentrating solar collector for electricity generation. J. Applied Phys.

Quaia, S., V. Lughi, M. Giacalone and G. Vinzi, 2012. Technical-economic evaluation of a Combined 
Heat and Power Solar (CHAPS) generator based on concentrated photovoltaics. Proceedings of the International Symposium on Power Electronics, Electrical Drives, Automation and Motion, Jun. 20-22, IEEE Xplore Press, Sorrento, Italy. DOI: 10.1109/SPEEDAM.2012.6264581

Riffat, S.B. and E. Cuce, 2011. A review on hybrid photovoltaic/thermal collectors and systems. Int. J. Low-Carbon Technol., 6: 212-241.

Rosell, J.I., X. Vallverdú, M.A. Lechón and M. Ibáñez, 2005. Design and simulation of a low concentrating photovoltaic/thermal system. Energy Convers. Manage., 46: 3034-3046.

Royne, A., C.J. Dey and D.R. Mills, 2005. Cooling of photovoltaic cells under concentrated illumination: A critical review. Solar Energy Mater. Solar Cells, 86: 451-483.

Schuetz, M.A., K.A. Shell, S.A. Brown, G.S. Reinbolt and R.H. French et al., 2012. Design and construction of a $\sim 7 \mathrm{x} \quad$ low-concentration photovoltaic system based on compound parabolic concentrators. IEEE J. Photovolta., 2: 382-386.

Shan, F., L. Cao and G. Fang, 2013. Dynamic performances modelling of a photovoltaic-thermal collector with water heating in buildings. Energy Build., 66: 485-494.

Sharaf, O. and M. Orhan, 2015. Concentrated Photovoltaic Thermal (CPVT) solar collector systems: Part I-fundamentals, design considerations and current technologies. Renewable Sustainable Energy Rev., 50: 1500-1565.

Sharan, S.N., S.S. Mathur and T.C. Kandpal, 1987. Analytical performance evaluation of combined photovoltaic-thermal concentrator-receiver systems with linear absorbers. Energy Convers. Manage., 27: 361-365.

Shockley, W. and H.J. Queisser, 1961. Detailed balance limit of efficiency of $\mathrm{p}-\mathrm{n}$ junction solar cells. J. Applied Phys., 32: 510-519.

Singh, B. and M.Y. Othman, 2009. A review on photovoltaic thermal collectors. J. Renewable Sustainable Energy.

Skoplaki, E. and J.A. Palyvos, 2009. On the temperature dependence of photovoltaic module electrical performance: A review of efficiency/power correlations. Solar Energy, 83: 614-264.

Sozen, A., T. Menlik and S. Unvar, 2008. Determination of efficiency of flat-plate solar collectors using neural network approach. Expert Syst. Applic., 35: 1533-1539.
Tripanagnostopoulos, Y., T. Nousia, M. Souliotis and P. Yianoulis, 2002. Hybrid photo-voltaic/thermal solar systems. Solar Energy, 72: 217-234.

Van Riesen, S., A. Gombert, E. Gerster, T. Gerstmaier and J. Jaus, 2011. Concentrix Solar's progress in developing highly efficient modules. AIP Conf. Proc., 1407: 235-238.

Verlinden, P.J., A. Lewandowski, H. Kendall, S. Carter and K. Cheah, et al., 2008. Update on two-year performance of $120 \mathrm{kWp}$ concentrator PV systems using multi-junction III-V solar cells and parabolic dish reflective optics. Proceedings of the IEEE 33rd Photovoltaic Specialists Conference, May 11-16, IEEE Xplore Press, San Diego, pp: 1-6. DOI: 10.1109/PVSC.2008.4922734

Xie, W.T., Y.J. Dai, R.Z. Wang and K. Sumathy, 2011. Concentrated solar energy applications using Fresnel lenses: A review. Renewable Sustainable Energy Rev., 15: 2588-2606.

Xu, G., X. Zhang and S.H. Deng, 2011. Experimental study on the operating characteristics of a novel low-concentrating solar photovoltaic/thermal integrated heat pump water heating system. Applied Thermal Eng., 31: 3689-3695.

$\mathrm{Xu}$, N., J. Ji, W. Sun, W. Huang and Z. Jin, 2015. Electrical and thermal performance analysis for a highly concentrating photovoltaic/thermal system. Int. J. Photoenergy. DOI: 10.1155/2015/537538

Yadav, P., B. Tripathi, S. Rathod and M. Kumar, 2013. Real-time analysis of low-concentration photovoltaic systems: A review towards development of sustainable energy technology. Renew Sustain Energy Rev., 28: 812-823.

Yamaguchi, M., T. Takamoto, K. Araki and N. Ekins-Daukes, 2005. Multi-junction III-V solar cells: Current status and future potential. Solar Energy, 79: 78-85.

Young, C.H., S.B. Riffat and E. Cuce, 2015. High capacity energy efficiency solar glass. Proceedings of the 14th International Conference on Sustainable Energy Technologies, Aug. 25-27, Nottingham, United Kingdom.

Zahedi, A., 2011. Review of modelling details in relation to low-concentration solar concentrating photovoltaic. Renewable Sustainable Energy Rev., 15: 1609-1614.

Zhao, J., Y. Song, W.H. Lam, W. Liu and Y. Liu et al., 2011. Solar radiation transfer and performance analysis of an optimum photovoltaic/thermal system. Energy Convers. Manage., 52: 1343-1353. 